\title{
Agricultural Value Added, Governance and Insecurity in Nigeria: An Empirical Analysis
}

\section{Edet Okon Anwana ${ }^{\star}$ \\ Aniefiok Benedict Udo ${ }^{2}$ Samuel Effiong Affia $^{3}$}

\author{
Department of Banking and Finance Akwa Ibom State Polytechnic, Ikot Osurua, Nigeria. \\ Email: anwanaedetokon@gmail.com Tel:+2348026205669 \\ 'Department of Economics Obong University, Obong Ntak, Akwa Ibom State, Nigeria. \\ Email: aniefiok.benedict@gmail.com Tel:+2348034042129 \\ ${ }^{s}$ Department of Business Administration, Akwa Ibom State Polytechnic, Ikot Osurua, Nigeria \\ Tel: +2348122300050
}

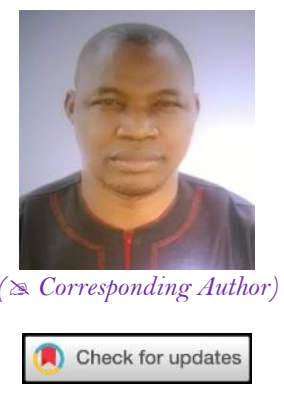

\section{Abstract}

Value added agriculture enables farmers to align with consumer preferences with quality characteristics not found in conventional raw material products. Agriculture value added could be under serious threat under poor governance situation and insecurity. This study was therefore undertaken to empirically evaluate the relationship between governance system, state of security and agriculture value added in Nigeria. The study made use of time series data sourced from World Bank Indicators, Central Bank of Nigeria, Institute for Economics and Peace, etc. The study employed Auto Regressive Distributed Lag (ARDL) bound testing procedure to examine the long and short run relationships between the variables. Diagnostic tests were successfully undertaken using Langrange multiplier, Ramsey's RESET, Jargue-Berra Normality and Heteroskedasticiy tests. The results show that in the long and short run, governance system in Nigeria insignificantly impact agriculture value added. However, security level and technology positively and significantly impact agriculture value added both in the short and long run. The study concluded that governance institutions in Nigeria which provide the means of control, policy formulation, implementation, etc are not effective enough to significantly enhance agriculture value added. On the other hand, though the country has experienced pockets of insecurity in some parts, the state of security has positively and significantly enhanced agriculture value added. The study recommends that policy formulations should be tailored to the short term and long term needs of agribusiness environment and investments. Also, tendencies that hamper the growth and development of the agric sector generally should be discouraged.

Keywords: Governance, Security, Agriculture, Value added, Institutions, Agric production, Agri-business

JEL Classification: Q13; 19.

\section{Introduction}

Nigeria is rated among countries that are well blessed with abundant human and natural resources, among which are arable land and human population of over 180 million people. As reported in Manyong et al. (2003) Nigeria has fairly high diversified agro-ecological conditions that make it suitable for the production of a wide range of agricultural products.

Agricultural sector is an important sector because it employs over $60 \%$ of the country's working population and over $70 \%$ of the total population depends on it for survival (Oyakhilomen and Zibah, 2014; Yusuf, 2014). Investment in agriculture will empower a more effective means of reducing hunger and poverty. Such investments tend to increase incomes and create social and economic ripple effects that engender economically strong and stable communities. Agriculture is the handmaid of industrialization and the largest user and abuser of natural resources, it checks inflationary tendencies by sustaining food supply which also is vital for human development. Further, it provides a market for industry sector products (Food and Agriculture Organization of the United Nations (FAO), 2002; Bill and Melinda Gates Foundation, 2011; Ugwu and Kanu, 2012).

Agriculture is generally seen as cultivation of plants of varied forms, and husbandry of animals or the management of living things and ecosystem or breeding of fishes to produce foods and services for the people (Nchuchuwe and Adejuwon, 2012). Though African counties produce a wide variety of agricultural products, economic benefits from such production have not yet been optimized. This is due in part to inadequate knowledge of appropriate value-adding technologies coupled with poor infrastructure facilities and absence of coherent policies to support such undertakings, especially in rural areas. Value added agriculture is a practice that enables farmers to align with consumer preferences with quality characteristics not found in conventional raw material products. They involve changing raw agriculture products into something more valuable through processing, drying, cooling, extracting and/or any other form of process that will transform the product from its raw form to a better 
quality or quantity through the key strategies of: changing physical state of products; producing enhanced products; differentiating products; bundling products; and producing more products that improve efficiency up the supply chain (Matthewson, 2007; Mmasa, 2013). So, they create avenues for farmers and agribusinesses to move from being price takers to price makers (Lu and Dudensing, 2015).

In the agricultural sector specifically, one critical condition for growth is good governance structure and related policies at all levels. UNEP (2008) warns that unless effective governance systems are in place, agricultural reforms, food security, poverty reduction and development will remain a tall dream. Through institutional and human governance capacities, public policies and strategies effectiveness can be achieved and better public decisions are made and implemented.

As shown in International Fund for Agricultural Development (IFAD) (1999) governance has three dimensions: economic; political; and administrative. Bringing these together, we can say that good governance defines the processes and structures that guide political and socio-economic relationships. Governance also relies on inclusiveness where equal participation and treatment of all people are exercised. It also assumes that corruption is minimized and the voice of even the most vulnerable are heard in decision making. However, weak governance in agriculture results from policy biases, underinvestment, wrong investment, lack of capacities, poor human resources management, targeting problems, leakages and procurement problems and absence of strong state and public sector organizations' interventions (United Nations Environment Programme (UNEP), 2008).

Agricultural sector like other sectors in an economy requires security. This is not only essential but is critical because it can attract or discourage development. However, one of the strong and recently recurring factors that seem to threaten agriculture productivity in Nigeria is the state of insecurity in the country. Achumbe et al. (2013) citing Global Peace Ranking identifies Nigeria as among the most unsecured and complex security environment in West Africa. As pointed out in Okonkwo et al. (2015) local or foreign business investors are not motivated to invest in an unsafe and insecure environment. Investors look forward to both high returns in investments and a safe environment for their investment. In the view of Nwanegbo and Odigbo (2013) security is freedom from danger or threats to a nation's ability to protect and develop itself, promote its cherished values and legitimate interests and enhance the well being of its people. It connotes protection against all forms of harm whether physical, social, environmental, political, economic or psychological and safety from all forms of harmful disruptions to peaceful coexistence (Achumbe et al., 2013; Umaru et al., 2015).

Insecurity is seen by many authors as the antithesis of security (Umaru et al., 2015; Adamu and Rasheed, 2016) and from Achumbe et al. (2013) common descriptions of insecurity are: wants of safety, danger, hazard, uncertainty, want of confidence, doubtful, inadequately guarded or protected, lacking instability, troubled, etc.

All these express vulnerability to harm, losses to life, property or livelihood, environmental destruction, and threat to nationhood. Insecurity could be caused by institutional incapability as a result of: government failure, pervasive inequalities and unfair treatment of people, ethnic and religious conflicts, perceptive conflicts between the people and government, weak and corruptible security system. Others are: loss of socio cultural and communal identity and value system, unprotected and porous boundaries, bad governance and lack of control, social irresponsibility of firms and corporate organizations, environmental pollution, unemployment, poverty, terrorism, frustration, cultism, corruption, etc. (Achumbe et al., 2013; Ajodo-Adebanjoko and Okorie, 2014; Obi, 2015; Adamu and Rasheed, 2016).

\subsection{Statement of the Problem}

Nwajiuba (2013) raised an alarm warning that the once dominant subsistence oriented form economy (of Nigeria) is at risk of gradual marginalization. Corroborating this, FAO (2002) alerts that agriculture in the less developed countries, Nigeria inclusive, is largely underdeveloped in production for local as well as international markets. Equally, agriculture value added is under serious threat by poor governance situation in addition to security situation in Nigeria.

Anwana et al. (2017) argue that, governance indicators and institutional quality in Nigeria is generally very weak and hence are inimical to investment, business growth and productivity. Also, since 1990 Nigeria has experienced heightened security situation and some parts of the country are affected. All these may distort the flow of farm inputs, crop yields and farm products, farming and processing, infrastructure and equipments, threatens customers' access to farms and farmers and consumers sources of supply. On the whole, they tend to work against agriculture value added and development generally.

Considering that there are linkages between good governance, security and agriculture value added. Also, considering that studies available that link the impacts of these variables together are relatively scarce for Nigeria, this study was undertaken to fill this gap and to empirically evaluate the relationship between governance system, state of security and agriculture value added in Nigeria.

\subsection{Research Hypotheses}

(i) There is no significant impact of governance institution on agriculture value added in Nigeria

(ii) There is no significant impact of state of security on agriculture value added in Nigeria

\section{Literature Review}

\subsection{Empirical Literature}

Oyakhilomen and Zibah (2014) studied the relationship between agricultural production and the growth of the Nigerian economy with focus on poverty reduction. The study made use of time series data analyzed using unit root tests and bounds (ARDL) testing approach to cointegration.

It was found that agricultural production in Nigeria was significant in influencing favorable trend of economic growth. However, poverty was found to still persist and increasing. So, despite significant impact of agriculture production on growth of the economy, poverty has not been reduced because the economy is basically reliant on oil to the neglect of the agriculture which employs more people and is rural. In a related study, Uche (2011) examined the impact of agricultural policy issues concerned with formulation, implementation and achievement of agriculture 
policies and programmes. The study used both primary and secondary data sources. The findings from the study indicate that agricultural policies in Nigeria are made based on inadequate data and there are implementation problems that negatively affect intended results. They argue that agricultural policies over the years in Nigeria has recorded partial success as indicated by problems of food security, hunger, malnutrition, low earnings from agriculture, etc.

Annes and Wright (2016) examined how women have been able to achieve empowerment and the ways in which value-added agriculture specifically foster an empowering context. The study used qualitative data drawn from interviews with French value-added farmers with diverse life experiences and trajectories. The findings of the study indicate that through the performance of value-added agriculture, women were able to engage in the process of empowerment. They were able to exercise authority in the daily management of their farm operations, explore and define their own methods of work, express creativity, satisfy needs for social ties and build a professional identity.

In a study of value addition and processing by farmers in developing countries, Tamru and Minten (2016) relied on unique data sets using a double hurdle technique. They examined factors that affect the decision and amount of selling coffee in red berries - the primary input for washing coffee- instead of the dried (value added) type. Results show that lack of access to wet mills, lack of enough red berry buyers, and bad quality coffee harvest reduce the likelihood of coffee sales in red berries form and hence a subsequent lower level of washed coffee. On the other hand, government's action of deciding designated selling dates, membership to a cooperative, and access to advances and loans increase the likelihood of selling coffee in red berries form.

In a related study, Mmasa (2013) examined the rationale of value chain in improving livelihood of the smallscale farmers in Tanzania. Data for the study was collected from secondary sources. The study revealed that agriculture sector has strong forward and backward linkages with other sectors. Low agriculture productivity was found to be due to low skills among the farmers and other stakeholders, no sufficiently strong farmers oriented agricultural research, extension services and training, for development of new technologies and no sufficient collection and dissemination of market information.

Thus, despite its great potential, the sector is facing a number of challenges including: low performance; low levels of production; low quality of output and low contribution to the national socio-economic goals; underutilization of available resources, limited market and value addition possibilities; and weak implementation of legal and regulatory framework.

Adeyemo et al. (2015) explored the relationship between agriculture value added and current account balances in Nigeria using data from different sources from 1980 to 2013. The study found that agriculture value added has a negative relationship with current account balances in the country in both the long run and the short run. The short run adjustment parameters however showed that agricultural value added as a percentage of the GDP as well as the net foreign assets are the only variables capable of adjusting to their long run equilibrium within the economy.

In a study on insecurity in Northern Nigeria, Adamu and Rasheed (2016) highlighted that Northern Nigeria, with reasonable population of citizens living on agricultural sector, among other regions of the country has witnessed various degrees of insecurity. This has affected the economic fortunes of the people including fortunes from farms, livestock and movements.

Hence, the overall standard of living of the people has been negatively affected. The situation has threatened development and foreign investments, and has disrupted social activities and peaceful coexistence. In a related study, Ajodo-Adebanjoko and Okorie (2014) argue that insecurity and conflicts that has continued to pose serious challenges to development in the country is caused by corruption that is prevalent in the country. Corruption is both an institutions variable of a country and a function of governance system.

Achumbe et al. (2013) took a study on the implication of insecurity in Nigeria in business investment and operations and sustainable development. They argue that the insecurity challenge in Nigeria negatively impinges on effective business activities and also on sustainable development processes.

In a similar study, Okonkwo et al. (2015) argue that insecurity constitute threat to lives and property, hinders business activities and discourages local and foreign investors with consequential negative effects that retards socio-economic development of the country. In a study on security challenges and economy of Nigerian state, Nwagboso (2012) using mostly secondary data argued that failure of successive government to address problems related to poverty, unemployment, inequitable distribution of income among different ethnic nationalities in the country gave birth to the insecurity problems we are experiencing now. They further argue that these insecurity problems consequently resulted to low government income, low participation rate of local and foreign investors in economic development and general insecurity of lives and properties.

\subsection{Theoretical Literature and Framework}

Agriculture value added includes processes or services in the supply chain that adds to or enhances the value of products to customers. They create avenues for farmers and agribusinesses to move from being price takers to price makers (Lu and Dudensing, 2015). There are solid theoretical basis that growth and value added in agriculture play key roles in economic growth of a country, studies such as Eswaran and Kotwal (1993), Echevarria (1997), Gollin et al. (2007), Johnston and Mellor (1961) are few of the many works cited to support this view. This gives reasons for linking agriculture value added and productivity theories to economic growth theories. One of such theories is the New Growth Theory.

This theory relies on the works of many authors among who is Robert Lucas Jnr and it emphasizes the importance of technological and institutional changes along with human capital formation in economic growth process of an economy (Lucas, 2002) adopted a dynamic optimization framework that incorporates individual preferences and focused on generating endogenous growth along a steady state equilibrium path of aggregate or single sector models. As noted in Olmstead and Rhode (2007) agriculture by employing non-reproducible inputs that are subject to diminishing returns fits uneasily into such models. To help analyze the invention and diffusion 
of new agriculture technologies, institutions as well as the linkages between the agriculture and non agriculture sector, the induced innovation hypothesis and threshold model are adopted.

The induced innovation hypothesis is associated with Hayami and Ruttan (1985), Olmstead and Rhode (1998) cited in Olmstead and Rhode (2007), Ruttan et al. (1978) etc. The hypothesis is a leading model that can be used to explain the creation of new technologies and holds on to the dynamics of long run factor substitution. It treats technology and institutions as endogenous responses to the forces of factor supply and product demand (Olmstead and Rhode, 2007). The threshold model is a standard tool that can be used to analyze timing and extent of technological diffusion. It concentrates on short run cost calculations and is associated with the works of David (1971), Olmstead and Rhode (2001) etc.

The new growth theory also emphasizes governance structure that enhances efficient adaptation and at the same time economizing costs of reaching agreements and resolving disputes (Masten, 2000; Kledal, 2003). Thus, firms will select the governance form that seeks to minimize transaction costs, under the conditions of bounded rationality and opportunistic behavior of partners. In the value chain, actors can protect themselves against risk of opportunism through joint ventures, monitoring systems and specific organizational arrangements such as contracts (Trienekens, 2011).

Since agriculture productivity as noted in Mozumdar (2012) is a function of conventional inputs of land, labor, water, chemicals, physical capital and as a function of non conventional factors of human capital, research and development, technology, resources management, governance system, policy reforms and security, etc. This study will therefore adopt the New Growth or Endogenous Growth theory to serve as its theoretical framework. This is so because among other theories, the new growth theory focuses on technology, human and physical capital, institutions, security, etc. as factors of agriculture productivity and value added suitable for an economy such as that of Nigeria.

\section{Methodology}

3.1. Description of Study Area

This study was undertaken for Nigeria, the most populous country in Africa with a vast agricultural space. The country has an estimated population of 182 million people as at November 2016 (Okpetu, 2016) with a total land area of $923,800 \mathrm{sq} \mathrm{km}$ and occupies about $14 \%$ of land area in West Africa. The country lies between $4^{\circ} \mathrm{N}$ and $14^{\circ} \mathrm{N}$ and between $3^{\circ} \mathrm{E}$ and $15^{\circ} \mathrm{E}$. It is located within the tropics with an average temperature of $27^{\circ} \mathrm{C}$. The climatic condition can be rated as fair; the wet coastal area has an annual rainfall above 3,500 mm while the Northern Sahel region has an annual rainfall of less than $600 \mathrm{~mm}$. The country enjoys a highly diversified agro-ecological condition suitable for a wide array of agricultural production, processing and other agro businesses

\subsection{Description of Data}

This study made use of time series data on agriculture value added, technology, governance, security, physical capital, covering the period from 1980 to 2017. The mean annual time series data of the selected variables were adopted for the study. Data for the study were sourced from World Bank Indicators, Central Bank of Nigeria, The GlobalEconomy.com, The Conference Board, Institute for Economics and Peace, etc.

\subsection{Analytical Framework}

To test for the level of relationship between the variables used in this study, correlation analyzis was undertaken and presented in a matrix format. The correlation analysis results helped us to determine which of the variables to drop or use for further analysis. The study employed the Auto Regressive Distributed Lag (ARDL) bound testing procedure to help examine the long run as well as the short run relationships between agricultural value added and its determining variables. The bound testing may not require pre-testing the variables of the model for unit roots because it is suitable even where the variables are not integrated of the same order. It is however necessary to conduct a unit root test to ensure that none of the variables is integrated of order two or more, since for this test procedure, the computed F-Statistics are only valid for variables integrated of order one or zero. To test for unit roots the study adopted the Augmented Dicker-Fuller Tests (ADF), and Phillip-Peron (PP) Tests.

As note in Pesaran et al. (2001) the bound test is determined based on an estimated error correction version of ARDL model using the ordinary least square (OLS) estimates. Oyakhilomen and Zibah (2014) highlights that the bound testing procedure possesses some characters that make it more suitable than other models for a study of this nature and some of these characters are: (i) Unlike the Johansen Cointegration approach, it does not require all the variables to be integrated of the same order, although the order should not exceed one; (ii) it is suitable for small or finite sample data as used in this study; (iii) Unlike other multivariate cointegration models, it allows the cointegration relationship to be estimated using the OLS as long as the lag order of the model has been identified; (iv) It can be used to simultaneously determine both the long and short run parameters of the model.

Akaike Information Criteria (AIC) was used to determine the optimal lag length for the specified ARDL model. An F-Statistics test of the joint significance of the coefficients of the lagged levels of the variables was adopted in testing the null and alternate hypotheses of cointegration among the study's variables. The null hypothesis is given as: $\mathrm{H}_{0}: \mathrm{a}_{1}=\mathrm{a}_{2}=\mathrm{a}_{3}=\mathrm{a}_{4}$

While the alternate hypothesis is given as: $\mathrm{H}_{1}: \mathrm{a}_{1} \neq \mathrm{a}_{2} \neq \mathrm{a}_{3} \neq \mathrm{a}_{4}$

There are two sets of adjusted critical values that help provide the upper and lower bounds used for inference, one set assumes that all the variables are integrated of order zero $(\mathrm{I}(\mathrm{O})$ ) whole the other assumes that all the variables are integrated of order one $(\mathrm{I}(1))$. The null hypothesis was to be rejected where the computed F-Statistics fell above the upper bound critical value, otherwise, it was to be accepted if it fell below the lower bound critical value. However, where it was to fall in between the upper and lower bounds critical values, the result would be considered inconclusive.

Diagnostic tests were undertaken using Langrange multiplier test for residual correlation; Ramsey's RESET tests for functional form of the model, Jargue-Berra Normality tests and Heteroskedasticiy tests. 


\subsection{Model Specification}

We express the functional relationship between agriculture value added and its determining factors based on the prescriptions of the new growth model as shown in Equation 1 below:

$$
\text { AVAD }=f(T E C H, \text { GOV }, \text { SEC, })
$$

These variables are defined thus:

AVAD = Agriculture Value Added measured in current LCU;

TECH $=$ Technology measured in foreign direct investment (FDI);

GOV = Governance Institutions measured in Government effectiveness Index which measures the quality and independence of public and civil services, the quality of policy formulation and implementation and the level of government commitment to their policies (The Global Economy.com, 2017);

SEC $=$ Level or state of Security measured by Global Peace Ranking of GPI;

As recommended in Pesaran et al. (2001) the ARDL model specified in Equation 1 was expressed as unrestricted error correction model test for cointegration between the variables examined in this study as shown in Equation 2 below:

$\Delta \operatorname{AVAD}_{t}=\alpha_{0}+\sum_{i=0}^{\mathrm{p}} \alpha_{1} \Delta \mathrm{AVAD}_{\mathrm{t}-\mathrm{i}}+\sum_{i=0}^{\mathrm{p}} \alpha_{2} \Delta \operatorname{lnTEC}_{\mathrm{t}-\mathrm{i}}+\sum_{i=0}^{\mathrm{p}} \alpha_{3} \Delta \mathrm{GOV}_{\mathrm{t}-\mathrm{i}}+\sum_{i=0}^{\mathrm{p}} \alpha_{4} \Delta \mathrm{SEC}_{\mathrm{t}-\mathrm{i}}+\beta_{1} \mathrm{AVAD}_{\mathrm{t}-1}+$ $\beta_{2} \ln \operatorname{lEC}_{\mathrm{t}-1}+\beta_{3} \mathrm{GOV}_{\mathrm{t}-1}+\beta_{4} \mathrm{SEC}_{\mathrm{t}-1}$

After establishing cointegration, the long run relationship was estimated by employing the ARDL model specified as shown in Equation 3 below:

AVADt $=\beta_{0}+\beta_{1}$ AVAD $_{\mathrm{t}-1}+\beta_{2} \ln \mathrm{TEC}_{\mathrm{t}-1}+\beta_{3} \mathrm{GOV}_{\mathrm{t}-1}+\beta_{4} \mathrm{SEC}_{\mathrm{t}-1}(3)$

Also, the short run relationship was estimated using the error correction model specified in the form as shown in Equation 4 below:

$$
\Delta \mathrm{AVAD}_{t}=\alpha_{0}+\sum_{i=0}^{p} \alpha_{1} \Delta \mathrm{AVAD}_{\mathrm{t}-\mathrm{i}}+\sum_{i=0}^{p} \alpha_{2} \Delta \operatorname{lnTEC}_{\mathrm{t}-\mathrm{i}}+\sum_{i=0}^{p} \alpha_{3} \Delta \mathrm{GOV}_{\mathrm{t}-\mathrm{i}}+\sum_{i=0}^{p} \alpha_{4} \Delta \mathrm{SEC}_{\mathrm{t}-\mathrm{i}}+\delta \mathrm{Ecm}_{\mathrm{t}-1}+\varepsilon_{\mathrm{t}}
$$

Where: The variables AVAD, TEC, GOV, SEC, are as defined earlier;

$\alpha_{0}$ and $\beta_{0}=$ Constant terms

$\mathrm{p}=$ lag length;

$\alpha_{1}-\alpha_{4}=$ Short-run parameter coefficients of the first difference explanatory variables;

$\beta_{1}-\beta_{4}=$ Long run parameter coefficients of the explanatory variables

$\log =$ Logarithm

$\Delta=$ First difference operators

$\sum_{i=0}^{\mathrm{p}}=$ Sum of the lagged variables from zero periods

$\mathrm{t}=$ Time period in years

$\varepsilon_{\mathrm{t}}=$ white noise

$\delta=$ Speed of adjustment

$\mathrm{Ecm}_{\mathrm{t}-1}=$ Error correction term lagged for one period

\section{Data Analysis}

4.1. Tests for Correlation

Table-1.Correlation matrix

\begin{tabular}{c|c|c|c|c}
\hline Variables & LOG(AVAD) & GOV & LOG(SEC) & LOG(TEC) \\
\hline LOG(AVAD) & 1.000000 & & & \\
\hline GOV & -0.824763 & 1.000000 & & \\
\hline LOG(SEC) & 0.956639 & -0.864309 & 1.000000 & \\
\hline LOG(TEC) & 0.893614 & -0.699980 & 0.828795 & 1.000000 \\
\hline
\end{tabular}

From Table 1 most of the macroeconomic variables in the estimated model exhibited negative correlation coefficient between each other except technology (TEC) with agriculture value added (AVAD) and security (SEC) with (AVAD). This signifies that the variables in the estimated model are not correlated with each other and hence there is no problem of multi collinearity in the estimated model.

\subsection{Unit Root Tests}

Table-2.Augmented Dickey-Fuller (ADF) and Philip-Peron (PP) unit root tests results

\begin{tabular}{c|c|c|c|c}
\hline Tests & Variable & Level & First Diff & Decision \\
\hline $\boldsymbol{A D F}:$ & LOG(AVAD) & -2.119298 & $-3.879751^{* * *}$ & $\mathrm{I}(1)$ \\
\hline & GOV & -2.627541 & $-7.658036^{* * *}$ & $\mathrm{I}(1)$ \\
\hline & LOG(SEC) & $-5.086819^{* * *}$ & -4.111160 & $\mathrm{I}(0)$ \\
\hline & LOG(TEC) & -0.764503 & $-11.58418^{* * *}$ & $\mathrm{I}(1)$ \\
\hline $\boldsymbol{P P}:$ & LOG(AVAD & -0.179766 & $-4.068441^{* *}$ & $\mathrm{I}(1)$ \\
\hline & GOV & -2.957623 & $-15.07995^{* * *}$ & $\mathrm{I}(1)$ \\
\hline & LOG(SEC) & -0.919648 & $-7.773288^{* * *}$ & $\mathrm{I}(1)$ \\
\hline & LOG(TEC) & $-4.158377^{*} *$ & -11.41012 & $\mathrm{I}(0)$ \\
\hline
\end{tabular}

Note: **** signify significance at $1 \%$; ** signify significance at $5 \%$

From Table 2 the unit root test results using the Augmented Dickey Fuller (ADF) and Phillip-Peron (PP) tests indicate that in both results the variables are stationary mostly at first difference. The variables that are integrated at level are security (SEC) using the ADF tests and technology (TEC) using the PP tests. This results show that none of the estimated variables is stationary at second difference thereby not violating the ARDL assumption of no 
I(II). Hence, the variables are suitable for the estimation of the model. Further, these results show that the variables are not integrated of the same order and this justifies the use of bounds approach to cointegration over the conventional approaches that require the variables to be integrated of the same order.

\subsection{Tests for Cointegration}

Table-3. Johansen Cointegration Test Results

\begin{tabular}{|c|c|c|c|c|}
\hline Hypothesis: No. of Cointegrating Equations & Eigen Value & Max-Eigen Value & 0.05 Critical Value & Prob*** \\
\hline None* & 0.690325 & 39.85592 & 27.58434 & 0.0008 \\
\hline At most 1 & 0.365078 & 15.44458 & 21.13162 & 0.2590 \\
\hline At most 2 & 0.294258 & 11.84917 & 14.26460 & 0.1164 \\
\hline At most $3^{*}$ & 0.171384 & 6.391951 & 3.841466 & 0.0115 \\
\hline Hypothesis: No. of Cointegrating Equations & Eigen Value & Trace Statistics & 0.05 Critical Value & Prob** \\
\hline None* & 0.690325 & 73.54162 & 47.85613 & 0.0000 \\
\hline At most $1^{*}$ & 0.365078 & 33.68570 & 29.79707 & 0.0170 \\
\hline At most $2^{*}$ & 0.294258 & 18.24112 & 15.49471 & 0.0188 \\
\hline At most $3^{*}$ & 0.171384 & 6.391951 & 3.841466 & 0.0115 \\
\hline
\end{tabular}

Note: Trace test indicates 4 cointegrating eqns at the 0.05 level

Max-eigenvalue test indicates 1 cointegrating eqn. at the 0.05 level

* denotes rejection of the hypothesis at the 0.05 level

The Johansen cointegration test result shown in Table 3, indicates that there exist a long run relationship between the macro economic variables used in the model. This is evidenced in the Max-Eigen value which is greater than the critical value at 0.05 level of significance and indicating one cointegration equation. Also, the trace statistics value exceeds the critical value at 0.05 significant levels. So, there is cointegration in the model.

\subsection{ARDL Bound Test for Cointegration}

Table-4. Bound Test Results

\begin{tabular}{c|c|c|c|c}
\hline Computed F-Stat. Value & K & Critical Value Significance & Lower Bounds & Upper Bounds \\
\hline 9.514617 & 3 & $1 \%$ & 4.29 & 5.61 \\
\hline & & $5 \%$ & 3.23 & 4.35 \\
\hline \multicolumn{2}{l}{ Source: Author's computation using Eviews 9 } & $10 \%$ & 2.72 & 3.77 \\
\hline
\end{tabular}

Note: Critical values are based on Pesaran et al. (2001) Table CI (iii), Case III

$\mathrm{K}$ is the maximum lag order and chosen by the user.

From Table 4, the bound test result shows that F-Statistics is higher than the upper bound value in all the level of significances, this indicate that a long run relationship exist between the variables in the estimated model, hence the null hypothesis of no cointegration between the variables is rejected. This also confirms the Johansen cointegration results above.

\subsection{ARDL Cointegrating and Long Run Form}

Table-5. ARDL Long Run Form Coefficients

\begin{tabular}{c|c|c|c|c}
\multicolumn{6}{c}{ Dependent Variable: LOG(AVAD) } \\
\hline Regressors & Coefficient & Std. Error & t-Statistic & Prob. \\
\hline GOV & 0.040269 & 0.054773 & 0.735206 & 0.4707 \\
\hline LOG(SEC) & 0.098616 & 0.014015 & 7.036402 & 0.0000 \\
\hline LOG(TEC) & 0.431107 & 0.141491 & 3.046881 & 0.0064 \\
\hline C & 2.028102 & 0.432517 & 4.689071 & 0.0001 \\
\hline
\end{tabular}

Note: ARDL $(1,2,1,5)$ selected based on Akaike info criterion (AIC).

From Table 5, the long run impact of governance institutions (GOV) on the agriculture value added (AVAD) is not statistically significant though it is positive. The estimated coefficient of institutions of 0.04 implies that a 1 percent increase in institutions will increase agriculture value added by 4 percent ceteris paribus. The result also shows that state of security (SEC) in the country positively and significantly promote AVAD at the long run. The estimated coefficient of security level shows that a 1 percent increase in security level will positively impact AVAD by 9.8 percent. Further, the result indicate that technology (TEC) significantly and positively impact AVAD in the country. The estimated coefficient of technology indicates that a 1 percent increase in technology will lead to about 43 percent increase in AVAD. This seems to be true as technology is a major factor in promoting AVAD. The constant coefficient shows a significant positive impact on AVAD when all the macroeconomic indicators remain unchanged.

\subsection{Estimated Short Run Relationship}

From Table 6, the result shows that in the short run, governance institutions negatively and insignificantly impact AVAD in the first lagged year. However, security level and technology both have positive impact in the short run on AVAD respectively. Whereas security level is significant on first lag, technology is significant on second lag. The lagged coefficient of the AVAD shows the current year's AVAD positively and significantly impacts the level of AVAD development in the succeeding year.

The speed of adjustment coefficient for agriculture value added is 0.1425 indicating an adjustment speed of 14.25 percent. The ECM is correctly signed and is statistically significant. ECM value of 0.1425 is an indication that about $14 \%$ of distortions in the system can be corrected in the succeeding year or that $14 \%$ of disequilibria 
from previous year's shocks will converge back to long run equilibrium in the current year. The Durbin-Watson statistics of 2.0 indicates no autocorrelation between the variables and hence the result is good for economic analysis. The F-statistics which is a measure of the overall significance of the regressors in the model is statistically significant. The adjusted $\mathrm{R}^{2}$ shows that about 94 percent of the total variation in agriculture value added is determined by changes in the explanatory variables. This is a good fit for the model.

Table-6.Results of the ARDL Short Run Relationship

Dependent Variable: LOG(AVAD)

\begin{tabular}{l|c|c|c|c}
\hline Variables & Coefficient & Std. Error & t-Statistic & Prob. \\
\hline LOG(AVAD(-1)) & 0.372249 & 0.122518 & 3.038326 & 0.0103 \\
\hline GOV(-1) & -0.005760 & 0.011477 & -0.501842 & 0.6249 \\
\hline SEC(-1) & 0.047020 & 0.012774 & 3.680942 & 0.0031 \\
\hline LOG(TEC(-2)) & 0.153983 & 0.047011 & 3.275446 & 0.0066 \\
\hline ECM(-1) & -0.142521 & 0.237715 & -2.599547 & 0.0250 \\
\hline C & 1.382944 & 0.323293 & 4.277680 & 0.0011 \\
\hline R-squared & 0.978577 & Mean dependent var & 3.351627 \\
Adjusted R-squared & 0.946797 & S.D. dependent var & 0.061997 \\
S.E. of regression & 0.003508 & Akaike info criterion & -8.171703 \\
Sum squared resid & 0.000148 & Schwarz criterion & -7.410443 \\
Log likelihood & 130.4038 & Hannan-Quinn criter. & -7.938978 \\
F-statistic & 61.2539 & Durbin-Watson stat & 2.012701 \\
Prob(F-statistic) & 0.000000 & & \\
\hline Soure: Authors computation & Eving 9
\end{tabular}

Source: Author's computation using Eviews 9

Note: ARDL $(1,2,4,3,4)$ selected based on Akaike info criterion (AIC)

*Note: p-values and any subsequent tests do not account for model selection.

4.7. Diagnostic Tests

Table-7.ARDL Model Diagnostic Tests.

\begin{tabular}{l|c|c}
\hline LM Test Statistics & Chi Square values & Prob. \\
\hline A: Serial Correlation & $\chi^{2}(2)=1.9582$ & {$[0.1916]$} \\
\hline B: Functional Form & $\chi^{2}(1)=0.4727$ & {$[0.5060]$} \\
\hline C: Normality & $\chi^{2}(2)=3.7621$ & {$[0.1524]$} \\
\hline D: Heteroskedasticity & $\chi^{2}(1)=1.7403$ & {$[0.2056]$} \\
\hline NB: A = Lagrange multiplier test of test of residual serial correlation \\
B = Ramsey's RESET test using the square fitted values \\
C = Jarque-Berra test based on test of skewness and Kurtosis of residuals \\
D = Based on the regression of squared residuals on squared fitted values.
\end{tabular}

From the outcome of the ARDL model diagnostic tests shown in Table 7, Lagrange Multiplier test of residual serial correlation, Ramsey's RESET test, Jarque-Berra normality test and heteroskedasticity test were undertaken. The model passed all these tests which show that: there is no serial correlation thus the residuals are serially uncorrelated; the model has the correct functional form; sample for the estimated model are normally distributed; and there is no heteroskedasticity, rather, the model is homoskedastic.

\section{Discussion of Results and Implication for Agriculture Sector Development in Nigeria}

The results of this study show that in the long run, governance system in Nigeria does not significantly impact, even though it positively enhances agriculture value added. Also, in the short run governance institutions negatively and insignificantly impact agriculture value added. These results agree with Anwana et al. (2017) that, governance indicators and institutional quality generally in Nigeria are very weak and hence are inimical to investment, business growth and productivity, including agribusiness. The results also corroborate (Uche, 2011)who found that agriculture policies and programmes in the country are poorly implemented. This negatively affects intended results and leads to problems of food insecurity, hunger, malnutrition, low earnings from agriculture, etc.

The results from this study also indicate that security level in Nigeria positively and significantly impact agriculture value added both in the short and long run. However, the rate of impact is less than 10 percent. This is despite Global Peace Ranking that Nigeria is among the most unsecured and complex security environment in West Africa. And insecurity situations alarms raised by Achumbe et al. (2013), Okonkwo et al. (2015), Adamu and Rasheed (2016), Ajodo-Adebanjoko and Okorie (2014) etc. However, it should be noted that Nigeria with vast land mass and also largely populated. Besides security challenges posed by groups like Boko Haram may affect a minor segment of the country while the major parts of the country are still actively engaged in agribusinesses. Another thought is that most security problems experienced in the country are perpetuated in the urban areas while agribusinesses are mostly cited in the rural areas, this may thus pose negligible threat to agric value added in the country.

The study also indicates that technology positively and significantly enhances agriculture value added in the country both in the long and short run. As shown in Mmasa (2013) this may be attributed to the favorable security situation, skilled farmers, adaptation and development of innovative farming system backed by new technologies and effective dissemination of market information assisted by the better communication system brought about by internet infrastructure in the country now. 


\section{Conclusion}

As noted in Oyakhilomen and Zibah (2014) and Yusuf (2014) the agric sector is very important in Nigeria and investment in the sector is not only an effective means of poverty reduction, it can also create social and economic ripple effect the will engender economically strong and stable communities. From the study, we conclude that governance institutions in Nigeria which provide the means of control, policy formulation, implementation and commitments, etc are not effective enough to significantly enhance agriculture value added in Nigeria. On the other hand, though the country is experiencing pockets of insecurity in some parts, the state of security so far has positively and significantly enhanced agriculture value added. Further, technology has also contributed positively and significantly to the growth of agriculture value added in the country.

\section{Recommendations}

This study recommends as follows: that governance institutions in Nigeria should be enhanced and government should not only make policies but should effectively control the implementation of such policies. However, policy formulations should be tailored to the short term and long term needs of the agribusiness environment and investments. Also, tendencies that hamper the growth and development of the agric sector generally should be discouraged.

Though security is shown to enhance agriculture value added in Nigeria, it should be noted that this advantage can be lost if the security situation is not strengthened and total war declared against insurgencies, militancy, armed robbery, herdsmen attacks and other security vices. Such security challenges may threaten agriculture productivity and generally the agric sector, discourage local and foreign investors, farming and processing, development of infrastructure and equipments, threatens customers' access to sources of supply, etc. On the whole, insecurity tends to work against agriculture value added and development generally and may create tensions capable of undermining the unity of the nation at large.

Home grown technology should be promoted and adopted in the areas of processing, preserving and other activities involved in adding value to agriculture products. This will discourage the sale of raw agric products which attracts lower prices and encourage value added products which attracts higher prices and profits. Also, investors in agribusinesses should take advantage of internet innovation and facilities to seek new innovations, information gathering and marketing of their products.

\section{References}

Achumbe, I.C., S.O. Ighomereho and M.O. Akpor-Robaro, 2013. Security challenges in Nigeria and the implications for business activities and sustainable development. Journal of Economics and Sustainable Development, 4(2): 79-99.

Adamu, A. and Z.H. Rasheed, 2016. Effects of Insecurity on the internally displaced persons (IDPs) in Northern Nigeria: Prognosis and diagnosis. Global Journal of Human-Social Science: F Political Science, 16(1): 1-6.

Adeyemo, T.A., S. Ajijola, S.K. Odetola and V.O. Okoruwa, 2015. Impact of agricultural value added on current account balances in Nigeria. Journal of Economics and Sustainable Development, 6(4): 108-116.

Ajodo-Adebanjoko, A. and N. Okorie, 2014. Corruption and the challenges of insecurity in Nigeria: Political economy implications. Global Journal of Human-Social Science: F Political Science, 14(5): 11-16.

Annes, A. and W. Wright, 2016. Value-added agriculture: A context for the empowerment of french women farmers? Review of Agricultural, Food and Environmental Studies, 97(3): 185-201.Available at: https://doi.org/10.1007/s41130-016-0034-1.

Anwana, E.O., B. Akpan and A. Udo, 2017. Industrial policy reforms: Toward achieving sustainable industrialization for Nigeria. Paper Presented at 58th Annual Conference of Nigeria Economic Society Conference, Nicon Luxury Hotel, Abuja, 26th-28th.

Bill and Melinda Gates Foundation, 2011. Agricultural development strategy overview. United States: Global Development Program, August, Bill \& Melinda Gates Foundation.

David, P.A., 1971. The landscape and the machine: Technical interrelatedness, land tenure and the mechanization of the corn harvest in Victorian Britain, in Donald N. McCloskey, ed., Essays on a mature economy: Britain after 1840. Princeton, N.J.: Princeton University Press. pp: 145-205.

Echevarria, C., 1997. Changes in sectoral composition associated with economic growth. International Economic Review, 38(2): 431452.Available at: https://doi.org/10.2307/2527382.

Eswaran, M. and A. Kotwal, 1993. A theory of real wage growth in LDCs. Journal of Development Economics, 42(2): 243-269.Available at: https://doi.org/10.1016/0304-3878(93)90020-n.

FAO, 2002. The role of agriculture in the development of least-developed countries and their integration into the world economy. Rome, Italy: Publishing and Multimedia Service, Information Division, FAO.

Food and Agriculture Organization of the United Nations (FAO), 2002. The role of agriculture in the development of least-developed countries and their integration into the world economy. Rome, Italy: Publishing and Multimedia Service, Information Division, FAO.

Gollin, D., S.L. Parente and R. Rogerson, 2007. The food problem and the evolution of international income levels. Journal of Monetary Economics, 54(4): 1230-1255.Available at: https://doi.org/10.1787/888933289019.

Hayami, Y. and V.W. Ruttan, 1985. Agricultural development: An international perspective, Rev. and Exp. Ed. Baltimore: Johns Hopkins University Press.

International Fund for Agricultural Development (IFAD), 1999. Good governance: An overview. Executive Board - Sixty-Seventh Session. Rome: IFAD. pp: 8-9.

Johnston, B.F. and J.W. Mellor, 1961. The role of agriculture in economic development. The American Economic Review, $51(4): 566-593$.

Kledal, P.R., 2003. Analysis of organic supply chains - a theoretical framework. Ph.D. Dissertation at FOI (Danish Research Institute of Food Economics), Danish Research Institute of Food Economics.

Lu, R. and R. Dudensing, 2015. What do we mean by value-added agriculture? Choices Magazine, 4th Quarter, Agricultural \& Applied Economics Association, 30(4). Available from http://www.choicesmagazine.org.

Lucas, J.R.E., 2002. Lectures on economic growth. Cambridge, Mass: Harvard University Press. pp: 118-19.

Manyong, V., A. Ikpi, J. Olayemi, S. Yusuf, R. Omonona and F. Idachaba, 2003. Agriculture in Nigeria: Identifying Opportunities for Increased Commercialization and Investment. Main Report of Research Funded by USAID/Nigeria, University of Ibadan.

Masten, S.E., 2000. Transaction-cost economics and the organization of agricultural transactions. In Industrial Organization, ed. Baye, M. R. \& Elwert, B., New York: Elsevier Science.

Matthewson, M., 2007. Exploring value-added agriculture. Small farms. Corvallis: Oregon State University.

Mmasa, J.J., 2013. Value addition practices to agricultural commodities in Tanzania. Tanzania Country Level Knowledge Network (CLKnet), Policy Brief No: 20.

Mozumdar, L., 2012. Agricultural productivity and food security in the developing world. Bangladesh Journal of Agricultural Research, 35(1\&2): 53-69.

Nchuchuwe, F.F. and K.D. Adejuwon, 2012. The challenges of agriculture and rural development in Africa: The case of Nigeria. International Journal of Academic Research in Progressive Education and Development, 1(3): 45-61. 
Nwagboso, C., 2012. Security challenges and economy of the Nigerian State (2007-2011). American International Journal of Contemporary Research, 2(6): 244-258.

Nwajiuba, C., 2013. Nigeria's agriculture and food security challenges. Agriculture and Food Security, 4_Grean_Deal_Nigeria_Agriculture.

Nwanegbo, C.J. and J. Odigbo, 2013. Security and national development in Nigeria: The threat of Boko Haram. International Journal of Humanities and Social Science, 3(4): 285-291.

Obi, C., 2015. Challenges of insecurity and terrorism in Nigeria: Implication for national development. OIDA International Journal of Sustainable Development, 8(02): 11-18.

Okonkwo, R., P. Ndubuisi-Okolo and T. Anagbogu, 2015. Security challenges and the implications for business activities in Nigeria: A critical review. Journal of Policy and Development Studies, 9(2): 157-168.Available at: https://doi.org/10.12816/0011214.

Okpetu, L., 2016. Nigeria population currently 182 million - NPC. Concise News. Available from https://www.concisenews.global/.

Olmstead, A.L. and P.W. Rhode, 2001. Reshaping the landscape: The impact and diffusion of the tractor in American agriculture, 1910-1960. The Journal of Economic History, $61(3): 663-698$.

Olmstead, A.L. and P.W. Rhode, 2007. Conceptual issues for the comparative study of agricultural development. A Paper Facilitated by International Centre for Economic Research.

Oyakhilomen, O. and R.G. Zibah, 2014. Agricultural production and economic growth in Nigeria: Implication for rural poverty alleviation. Quarterly Journal of International Agriculture, 53(3): 207-223.

Pesaran, M.H., Y. Shin and R. Smith, 2001. Bounds testing approaches to the analysis of level relationships. Journal of Applied Econometrics, 16(3): 289-326.

Pesaran, M.H., Y. Shin and R.J. Smith, 2001. Bounds testing approaches to the analysis of level relationships. Journal of Applied Econometrics, 16(3): 289-326.Available at: https://doi.org/10.1002/jae.616.

Ruttan, V., H. Binswanger, Y. Hayami, W. Wade and A. Weber, 1978. Factor productivity and growth: A historical interpretation, in Binswanger, H \& Ruttan, V. (1978). Induced innovation: Technology, institutions, and development. Baltimore: Johns Hopkins University Press.

Tamru, S. and B. Minten, 2016. Value addition and processing by farmers in developing countries: Evidence from the coffee sector in Ethiopia. Invited Poster Presented at the 5th International Conference of the African Association of Agricultural Economists, Addis Ababa, Ethiopia, September. pp: 23-26.

The Global Economy.com, 2017. Nigeria: Government effectiveness. Available from www.theglobaleconomy.com/Nigeria/wb_government.

Trienekens, J.H., 2011. Agricultural value chains in developing countries a framework for analysis. International Food and Agribusiness Management Review, 14(2): 51-82.

Uche, I.P., 2011. The impact of agricultural policies on Nigerian economy. A Thesis Submitted to the Department of Public Administration and Local Government, Faculty of Social Sciences, University of Nigeria, Nsukka.

Ugwu, D.S. and I.O. Kanu, 2012. Effects of agricultural reforms on the agricultural sector in Nigeria. Journal of African Studies and Development, 4(2): 51-59.

Umaru, A., H.A. Pate and A.D. Haruna, 2015. The impact of insecurity and poverty on sustainable economic development in Nigeria. International Journal of Humanities Social Sciences and Education, 2(2): 32-48.

United Nations Environment Programme (UNEP), 2008. Governance and agriculture. One Nature, On World, Our Future, COP 9 MOP 4, Bon Germany.

Yusuf, S.A., 2014. Role of agriculture in economic growth \& development: Nigeria perspective. Munich Personal RePEc Archive (MPRA) Paper No. 55536.

Citation | Edet Okon Anwana; Aniefiok Benedict Udo; Samuel Effiong Affia (2019). Agricultural Value Added, Governance and Insecurity in Nigeria: An Empirical Analysis. Asian Business Research Journal, 4: 1-9.

History:
Received: 7 January 2019

Received: 7 January 2019
Revised: 12 February 2019

Accepted: 15 March 2019

Published: 25 April 2019

Licensed: This work is licensed under a Creative Commons

Attribution 3.0 License (cc)

Publisher: Eastern Centre of Science and Education

Acknowledgement: All authors contributed to the conception and design of the study.

Funding: This study received no specific financial support.

Competing Interests: The authors declare that they have no conflict of interests.

interests. Transparency: The authors confirm that the manuscript is an honest,
accurate, and transparent account of the study was reported; that no vital accurate, and transparent account of the study was reported; that no vital
features of the study have been omitted; and that any discrepancies from the study as planned have been explained.

Ethical: This study follows all ethical practices during writing.

Eastern Centre of Science and Education is not responsible or answerable for any loss, damage or liability, etc. caused in relation to/arising out of the use of the content. Any queries should be directed to the corresponding author of the article. 